\title{
KAPOSIZOLTÁN:" A dél-dunántúli gazdasági elit változásai (1945-1968)
}

The previous economic and social elite lost its influence after the World War II. They were chased, sentenced to prison and many of them were tortured to death. The Communist Party's local members were appointed to be managers of large estates and factories. They were the so called „worker directors". Their tasks were the dismissal of the previous managers and the launch of the planned-economy. Large estates were parceled in 1945. In the ages 1950 the owners of these parceled lands established farmers' co-operative. Some well-functioning manors were transformed to large state farms. The selection of executives was based on how loyal to the Communist Part they were. Because of these, the productivity of the agriculture and the industry declined.

A Dél-Dunántúl térsége évszázadokon át alapvetően mezőgazdasági vidék volt. A több ezer holdas nagybirtokokon folyó nagyüzemi termelés jelentette sokáig az agrártermelés minöségi részét. A birtokszerkezeten belül a nagybirtok aránya hosszú távon csökkent, de még így is hatalmas területek koncentrálódtak az arisztokraták kezén. A mezőgazdasági nagyüzemi termelés mellett nagy szerepe volt a paraszti gazdálkodásnak is. A két világháború között a térség megyéiben az agrárfoglalkozásúak nagyjából 70\%-ot tettek ki az összes keresőböl (Népszámlálás 1930). A mezőgazdaság mellett a 19. század közepe óta gyorsan fejlödött az ipar is, föleg a nagyobb városokban (Pécs, Kaposvár, Nagykanizsa) alakultak ki a jelentösebb ipari kapacitások. A Dél-Dunántúl négy megyéjében a 2. világháború előtt mintegy 140 gyár müködött (T. Mérey 1979), de továbbra is nagy szerepe volt a tradícióit örzö helyi kis-és középiparnak. Fontos eleme volt a gazdasági életnek a kereskedelem, s a hozzá szorosan kapcsolódó közlekedés és pénzügyi szolgáltatások rendszere. A városok foglalkoztatásában a kereskedelem, a pénzügy és a közlekedés ágazatai nagyjából 7-10\%-ot tettek ki, a legmagasabb arány az 1930-as években Nagykanizsán figyelhetö meg, ahol ekkor a keresöknek több mint 17\%-a dolgozott ezekben az ágazatokban (Népszámlálás II. 1930). Mindazonáltal tény, hogy igen kevés városi funkcióval rendelkező település volt a térségben. A hatályos törvényi besorolás szerinti csak hat város volt a térségben: Pécs, Kaposvár, Nagykanizsa, Zalaegerszeg, Szekszárd, valamint Mohács. Közülük Pécs volt alapvetően ipari település, ahol az iparban és a bányászatban dolgozók aránya 1930-ban 40\%-os volt, ezzel szemben Kaposvárott 33, Nagykanizsán pedig csak 28\%-nyian szerezték jövedelmüket az iparból.

A háború elötti a gazdasági elit többnyire a nagybirtokosokból, gyárosokból és a nagykereskedőkből állt. Azonban a gazdasági elit szempontjából a három ágazat korántsem volt kizárólagos! A legtöbb adót fizetök listáját szemlélve látszik, hogy közöttük nagy számban szerepelnek pl. a városi és megyei közigazgatási pályán sikeres emberek, a bankok, takarékpénztárak tulajdonosai, részvényesei, a magánügyvédek és a jogászok. Nagykanizsán például a háború elött a húsz legtöbb adót fizetỏ közül hat ügyvéd, vagy egyéb jogászi tevékenységet folytató személy volt (Zalai Közlöny 1933. 12. 1.). Pécsett a gazdasági elit tagjai között a pénzügyi szolgáltatásban dolgozók, a kereskedők, illetve a magánpraxist folytató jogászok foglaltak helyet nagy számban, de az elitbe tartoztak az állami üzemek egységeinek vezetöi is. (Bérdi, 1980) Ebböl is látható, hogy a háború elött a gazdasági elit rekrutációja széles volt.

\footnotetext{
• MTA-doktora (DSc.), egyetemi tanár - Pécsi Tudományegyetem Közgazdaságtudományi Kar Közgazdasági- és Regionális Tudományok Intézete.
} 
A 2. világháború utáni szovjet témyerés erőteljesen korlátozta a korábbi gazdasági elitet. A háború alatt a németbarát arisztokraták és középbirtokosok, avagy a horthysta és a nyilas hatalmat kiszolgáló földbirtokosok jó része elmenekült az országból. A zsidó bérlök és földtulajdonosok többségét 1944-ben koncentrációs táborba hurcolták, s megöltėk. Mivel sok nagybirtokos nem folytatott politikai tevékenységet, így azt várhatták, hogy tevékenységüket a szovjet bevonulás után is tudják majd folytatni. Ez azonban végzetes tévedés volt. A kommunista párt a nagyobb tulajdonnal rendelkező birtokosokat perbe fogta, $\mathrm{s}$ kreált ítéletekkel börtönbe zárta. Az 1945. évi földreform végrehajtása amúgy is megfosztotta a nagybirtokosokat korábbi vagyonuk jelentős részétöl. A rendelet szerint az 1000 kat. holdnál nagyobb földeket kisajátították, s felosztották; az erdők és legelők állami kézbe kerültek; az 1000 hold alatti birtokosok pedig korábbi földjeikböl csak 100 holdat tarthattak meg. Mindennek eredményeképpen a korábbi nagybirtokosok befolyása nagyban lecsökkent.

Akik közülük itthon maradtak, azokat a hatalom 1950-51 során nagyrészt likvidálta. Így például Baranya megyében a szentegáti uradalom egykori tulajdonosát, báró Biedermann Imrét, aki ismert volt szociális és karitativ tevékenységéről és az általa vezetett mintagazdaságról, 1949-ben koholt vádak alapján letartóztatták. Biedermann egy évvel később a börtönben csontvázzá lefogyva éhen halt. A Somogy megyei kivadári uradalom egyik tulajdonosát, gróf Somssich Lászlót a kistarcsai, majd később a recski kényszermunkatáborba hurcolták; testvére, Somssich Zsigmond a hortobágyi munkatáborba került. Az alsóbogáti uradalom tulajdonosát, az öreg Inkey Lászlót 1951-ben telepítették ki, s Hácspusztán, a család egykori birtokának viskójában halt meg 91 éves korában. A Somogy megyei Hárságyon birtokos gróf Zichy Jenönek már 13 évesen dolgoznia kellett: a Mecseki Állami Erdögazdaságnál volt kocsis, később állatetető lett. A bólyi uradalommal rendelkezö Montenuovo Nándor herceg 1951-ben a fogva tartása során elszenvedett bántalmazások következtében kórházban halt meg. (A felsorolt példák: Kaposi, 2009.) Világos, hogy a régi gazdasági elit földbirtokosi csoportja teljesen elvesztette befolyását.

A hazai iparosok és kereskedök legalább ennyit vesztettek, hiszen esetükben is a vagyon elvesztése mellett fizikai létük is veszélyben forgott. Ennek a csoportnak a kiszoritására és felszámolására is sok példánk van. Kaposvárott volt egy húsüzem, amit Graumann Viktor, egy budapesti és pécsi húsipari vállalkozó hozott létre 1938-ban. A mindenkori hatalmat a jegyrendszer miatt kényszerböl kiszolgáló Graumann a kommunisták első számú ellenségévé vált. A város az üzemböl községi élelmiszerüzemet kívánt létrehozni. 1948 során megindult eljárás végén a vállalkozót 7 év fegyházra ítélték (Kaposi 2001). A pécsi Zsolnay gyár több szempontból is céltáblává vált. Mivel a gyár vezetōje, Mattyasovszky-Zsolnay Tibor 1944ben a német megszálláskor kényszerböl elszállásolta a város német parancsnokát, ezért sok jóra nem számithatott. 1948-ban államositották a gyárat, majd pedig mindent, ami a családhoz tartozott (telkeket, a szölöt, lakást stb.) elvettek. Az itthon maradt családtagokat 1951ben koncepciós perben elítélték (Romváry 2002). Súlyos börtönbüntetést szabtak ki a férfiakra, a gyerekeket pedig intézetbe adták. Közismert példa a pécsi Angster-orgonagyár esete. A világhíü vállalkozás $60-100$ embert foglalkoztató középüzem volt, szoros egyházi intézményi kapcsolatokkal. A gyár államosítására 1949 végén került sor. Az üzemnek új feladatot adtak, a továbbiakban asztalosipari tevékenységet kellett végezni, többek között koporsókat gyártottak; a volt tulajdonosra hosszú börtönbüntetés várt (Angster 1993).

Lényeges kérdés, hogy kik kerültek az egykori tulajdonosok helyére. A térségben nagyjából az országos mintának megfelelően zajlott a vállalatvezetők kicserélödése. Első lépésként minden üzemben a szakszervezetekre alapozva megpróbáltak egy-egy kommunista csoportot felépíteni. A második lépésként a gyenge közellátás miatt elégedetlen munkástömegeket szembe forditották a tulajdonosokkal, amivel erős tulajdonos-ellenes hangulatot teremtettek. A harmadik lépés az államosítás volt, amikor is a központi kommunista vezetés a helyi üze- 
mekben a kommunista üzemi szervezet vezetőjének adta gyárirányítás lehetöségét. Ebben az idöszakban a párthoz való feltétlen hüség volt az üzemekben a meghatározó; szinte egyáltalán nem volt szükséges magasabb képzettség vagy valamilyen vállalatvezetői tapasztalat. Elöfordult, hogy az újdonsült vállalatvezetönek irás- és olvasási nehézségei is voltak.

A fenti folyamatra sok esetünk van. A Pécsi Börgyár esetében 1948. március 25-én Budapesten, a Vasas-székházban egy timársegéd tehetett vezetöi fogadalmat. Az új vezetö korábban alapitója volt a börgyári kommunista szervezetnek, aki 1948-ban éppen a párttitkári funkciót is betöltötte, ö lett az első munkásigazgató. Vállalatvezetöként a legfontosabb tevékenysége a volt tulajdonosi, részvényesi, igazgatói kör eltávolítása, valamint a termelés folyamatosságáról való gondoskodás volt (Jakab 1999, Jakab 2002). Egy másik eset a Hamerli-kesztyügyár esete, ahol Sztipánovics József volt munkás foglalhatta el 1948. március 27-én a vezetöi pozíciót az államosított gyárban (Déri 1977). A pécsi Zsolnay-gyárban az új munkásigazgató Dallos Kovács József lett, aki korábban kemencemunkásként dolgozott (Kehidai 1999). Ezek a példák is világosan mutatják, hogy a kezdeti időkben egyértelmüen a lojalitáskritériumoknak való megfelelés volt az elsödleges az új vállalatirányító réteg kialakulásában. Mivel Pécs város alapvetöen ipari település volt, $\mathrm{s}$ emiatt mindig erös volt a baloldal, ezért sokkal nagyobb arányban válhattak a kommunista dolgozók vezetökké, mint az országban. Hasonló folyamatok zajlottak Kaposváron is. 1948. március utolsó napján három munkásigazgató vehette át kinevezését: a cukorgyárhoz Vajda Gyula, a Helios konzervüzemhez Madarász Lajos, a malomhoz pedig Rozsi János (Andrássy 1975). Az is kiderül a forrásokból, hogy a munkásigazgatók kinevezési gyakorlata megosztotta a vállalatok dolgozóit, sokan vélekedtek úgy, hogy az államosításnak s a vele együ̈t járó tisztogatásnak nem nagyon volt értelme.

Az új munkásigazgatók a tisztogatás elvégzésén túl általában semmit nem tudtak hozzá tenni a vállalat müködéséhez. Az 1940-50-es évek fordulóján a dél-dunántúli üzemek müködését központilag sokszor átszervezték, amitől az eredményesség javulását várták. Tegyük hozzá mindjárt, hogy a stratégiai kérdések Budapesten, a pártközpontban dőltek el, a munkásigazgatók ebbe nem szólhattak bele, tevékenységük egyszerü végrehajtásra korlátozódott. Esetükben kompetenciakritériumok nem merültek fel. Ennek következménye volt, hogy a munkásigazgatók - akárcsak az ország más vidékein - gyakran cserélödtek. A központi hatalom sajátos káder-rotációt hajtott végre, aminek eredményeképpen sokszor évente-kétévente váltották a vezetőket a vállalatok élén (Valuch 1999). Az 1950-es évek vezetöi esetében továbbra is megmaradt a párthüség, mint elsődleges kiválasztási elem, s egyre nagyobb számban kerültek üzemek élére a munkáscsaládokból származók. Változás ebben a folyamatban majd csak az 1956. évi forradalom után történt, amikor néhány fontosabb gazdaságvezetöi poszton megjelenhettek már akár párton kívüli értelmiségiek is. Az iparfejlesztés és annak szakemberigénye miatt egyre nagyobb kereslet volt nehéz- és gépipari szakemberek iránt, ami az 1960-as években már egy új gazdasági vezetői réteget termelt ki. Ez volt az a származása és szakértelme alapján érvényesülö technokrata káder-elit, amely a pártvezetésben vagy amellett egyre eröteljesebben befolyásolta a rendszer müködését (Lengyel 2007).

Hasonló problémákkal küszködött a dél-dunántúli mezögazdaság irányitása is. Az 1940-50es évek fordulóján megindított eröszakos kolhozosítás eredménye elég siralmas volt. Az eröszakosság ellenére a közép- és gazdagparasztság nem lépett be tsz-ekbe, így azok alapvetöen nagyon kevés földdel rendelkeztek. Ezt a nevïk is mutatta, hiszen leginkább földmunkásszövetkezeteknek hivták öket. Vezetőik sokszor korábban földnélküli cselédekböl, vagy a földosztásnál egy kevés földet szerzett baloldaliakból álltak. Itt is a lojalitás, a pártakarat képviselete volt a meghatározó elem a vezetői rekrutációban. Igazából ebben az időben a tsz-ek élére kerültek esetében nem is volt szükség komolyabb képzettségre, hiszen ezek a szövetkezetek nem tudtak nagyüzemszerüen müködni. A pártirányítás és a szövetkezetekbe belépök között, föleg, ha esetleg képzettebb, gazdagabb elemek is bekerültek, igen komoly összeütközések is 
történetek; a képzettebbek sokszor kiközösítették a rájuk telepített pártvezetőket, akik viszont jelentős eröszakkal válaszoltak. 1953-ban aztán - Nagy Imre kormánya alatt - lehetőség nyílott a tagságnak a tsz-ek elhagyására. Nem véletlen, hogy a tsz-tagság mintegy fele pár hét alatt ki is menekült a tsz-ekböl (Kaposi 2007).

A tsz-szervezés második időszaka (1959-61) azonban már nagy változásokat hozott. A DélDunántúlon is igyekeztek a sokszor jól müködő, 10-20 holdas gazdasággal rendelkezö középparasztokat megnyerni, s ezzel a tsz-tagság kohézióját erösíteni. Ezek a középparasztok tszelnökként aztán még hosszú évekig vezették a megszervezett tsz-eket. Magyarországon 1962ben a közel 4000 tsz-elnök közül csak 155 fönek volt felsöfokú diplomája, vagyis a falvakban ekkor nem volt szükség szakképzett, hatékony vállalatirányítási képességekkel rendelkező vezetőkre (Valuch 1999). Az újonnan megszervezett tsz-ek az 1960-as évek második felében elindult gépesítés következtében egyre inkább mezőgazdasági nagyüzemekké válhattak. Ez azt is magával hozta, hogy a nagyüzemekben már egyre nagyobb számban volt szükség agrármérnökökre, képzett kertészekre stb. A falusi gazdasági elit jelentősen kibövült, amiben persze nagy szerepe volt az 1970 óta Kaposváron a föiskolai gazdászképzés megindulásának. Az 1971-ben induló intézmény nagyszámú gazdász-szakembert tudott kibocsátani, ami érdemben hozzájárult a térség mezögazdasági fellendüléséhez (Mo. a XX. században, 1999). Tegyük még hozzá, hogy tsz-elnöknek lenni egyben köztes pozíciót jelentett: felfelé a pártelvárásoknak kellett megfelelni, lefelé pedig a tagság elvárásait kellett valamilyen szinten teljesiteni. Nagy szerepe volt a tsz-ek müködésében az informális szektornak, a pártvezetéssel együitt folytatott vadászatoknak, a pártvezetök konyhája feltöltésének, ami a tsz számára a pénzügyi szubvenciók kijárását, fejlesztési források megszerzését biztosithatta.

A földosztás után sok állami gazdaság jött létre a térségben. Ezeket gyakran olyan földeken szervezték meg, amelyeket a földreform során valamiért nem osztottak ki. İgy például a báró Puchner féle bikali uradalom mintegy 1000 holdján szervezödött állami agrámagyüzem (Ódor 2001). A volt Montenuovo bólyi uradalom is állami gazdasággá vált, akárcsak a Pécs mellett található üszögpusztai Grósz, avagy a már említett szentegáti Biedermann-uradalom. Érdekes volt már a szerveződése is az állami gazdaságoknak, hiszen ahol sok kicsi kis állami gazdasági egység jött létre, azokat a későbbiekben koncentrálták. Ilyen volt pl. a bólyi, vagy éppen a Szigetvár melletti Görösgáli Ảllami Gazdaság is (Iglói 1970, Görösgál 1970). De említhetnénk a villányi állami gazdaságot is, amely 1945-ben Szölészeti és Borászati Szakiskolaként alakult meg, majd 1949-ben Szőlőoltvány-termelö Állami Gazdaság lett, majd 1961-töl Villány, Siklós és Beremend állami gazdaságainak összevonásával Villány-Siklósi Állami Gazdaságként müködött tovább (Kovács 1970). A szentegáti üzem viszont teljesen ellentétes, hiszen ott a nagyjából egyben maradt nagyüzem tovább müködhetett az állami gazdaság létrehozásakor. $\mathrm{Az}$ állami gazdaságokban is a kommunista párt emberei felügyelték a munkát. Lényeges azonban, hogy itt a pártirányitás mellett nagyobb szerep jutott a kompetenciakérdéseknek. Szentegáton például a 35 aranykoronás földeken magas hozamokat lehetett produkálni, nem véletlen, hogy jelentős szakembergárda települt oda. Az állami gazdaságok sokszor a kísérletezés, a fejlesztés kisérleti üzemeit jelentették, így itt mindig erösebben érvényesülhetett a szakértelem. Így pl. a Pécsi Állami Gazdaság a hústermeléssel és gyümölcstermeléssel foglalkozott; Kaposvárott fejlesztették ki a Kahyb hússertés hibridet, Bikalon a halászati üzem vált kiemelkedövé, Bólyhoz a szójatermelési kísérletek kapcsolódtak stb.

Látható mindebböl, hogy a háború elötti gazdasági elit szinte mindegyik rétegét jelentős hatalmi támadás érte az 1940-es évek végétől kezdve. A korábbi földbirtokosok, iparosok, kereskedök tevékenysége a polgári modellre épült, aminek alapja a magántulajdon sérthetetlensége volt. Az új kommunista hatalom azonban pillanatok alatt felrúgta ezt a modellt, $s$ ellenségnek tekintette a régi rend képviselöit. Mivel a gazdaság müködését (a termelést, az elosztást, a fogyasztást) központilag tervezték meg, ezért az egyéni kvalitásoknak alig jutott szerep. Az ural- 
kodó pártnak a gazdaság élén alapvetően végrehajtókra volt szüksége. A régi közigazgatási vezetők, a hagyományos polgári értelmiség, a gazdasági szakemberek feleslegessé váltak. Ezzel párhuzamosan az uralkodó elit lépéseket tett annak érdekében, hogy a tudatos ellenségkép fenntartásával a társadalom alsó rétegeiből emeljen fel és iskolázzon ki rendszerhü támogatókat, megnyitva elöttük az érvényesülés csatornáit. Makrogazdaságilag az 1950-68 közötti korszak óriási változás volt Magyarországon, de egyben visszalépés a piaci rendszertöl egy felülről irányított keleti (ázsiai) modell felé. Egyben okozója lett annak is, hogy két évtized alatt a vállalkozói hajlamot, az önálló termelés és fejlesztés gondolatát sikerült tartósan leépíteni a társadalomban. Ezzel a létrehozott gazdaságpolitikai modell hozzájárult az ország hosszú távú gazdasági gondjainak elöidézéséhez, s egyben máig tartó problémákat teremtett.

\section{Irodalomjegyzék}

Andrássy, A. (1975): A felszabadult város (1944-48). In: Kaposvár. Várostörténeti tanulmányok. Kaposvár.

Angster, J. (1993): Angster. A pécsi orgonagyár és a család története. Pro Pannónia. Pécs.

Bérdi, Gy. (1980): Pécs legnagyobb adófizetôi 1873-1926. Doktori disszertáció kézirata (ELTE Történelem Tanszék Könyvtára D/320). Pécs-Budapest.

Déri, J. (1977) A pécsi kesztyüipar kialakulása és története a Hamerli kesztyügyár államositásáig. In: A Pécsi Kesztyügyár története 1861-1976. Pécs.

Görösgál (1970): 20 éves a Görösgáli Állami Gazdaság (1949-1969). Pécs.

Iglói Z. (1970): A Bólyi Állami Gazdaság. Pécs.

Jakab A. (1999): Fejezetek a Pécsi Börgyár történetéböl (1889-1989). In: Angstertöl Zsolnayig. Ipartörténeti tanulmányok. Pécs.

$J a k a b$ A. (2002): A Pécsi Börgyár igazgatóinak müködése. In: Iparosok és bányászok a Mecsekalján. Gazdaságtörténeti tanulmányok. Pro Pannónia Kiadó. Pécs.

Kaposi Z. (2001): Kaposvár iparának története (1945-2000). In: T. Mérey Klára-Kaposi Zoltán: Kaposvár ipartörténete. Kaposvár.

Kaposi Z. (2002): Magyarország gazdaságtörténete 1700-2000. Dialog Campus Kiadó. Budapest-Pécs.

Kaposi Z. (2006): Pécs gazdasági fejlödése (1867-2000). P-BKIK. Pécs.

Kaposi Z. (2007): Die Entwicklung der Wirtschaft und Gesellschaft in Ungarn 1700-2000. Verlag Schenk. Passau.

Kaposi Z. (2009): A gazdasági elit változásai a Dél-Dunántúlon. In: Válságos idők tegnap és ma. Pénz, gazdaság és politika a 19-21. században. Pannónia könyvek. Pécs.

Kehidai L (1999): A Zsolnayak. In: Angstertöl Zsolnayig. Ipartörténeti tanulmányok. Pécs.

Kovács $A$. (1970): Villány község élete a múltban és a jelenben. Pro Pannónia Kiadó. Pécs.

Lengyel Gy. (2007): A magyar gazdasági elit társadalmi összetétele a huszadik század végén. Akadémiai Kiadó. Budapest.

Magyarország a XX. században. www.mek.oszk.hu.A vidéki agrár-felsőoktatási intézmények.

T. Mérey K. (1979): Zala megye gyáripara 1944. elött. In: Közlemények Zala megye közgyüjteményeinek kutatásaiból 1979. Zalai gyújtemény, 12. Zalaegerszeg.

T. Mérey K. (1985): A Dél-Dunántúl iparának története a kapitalizmus idején. Akadémiai Kiadó. Budapest.

Népszámlálás (1930): Az 1930. évi népszámlálás. I. rész. Demográfiai adatok. Budapest, 1932.; illetve: Az 1930. évi népszámlálás. II. rész. Foglalkoztatási adatok. Budapest, 1934.

Ódor I. (2002): Bikal. (Száz magyar falu könyvesháza.) Budapest.

Romváry F. (2002): A Zsolnay-gyár 1945 után. In: Iparosok és bányászok a Mecsekalján. Pécs.

Somssich-Szógyény, B. (2005): Alaprajz. Holmi, 2005. július.

Szili F. (1986): A cukorrépa termesztése Délkelet-Dunántúlon és a MIR kaposvári cukorgyára 1893-1948. Somogy Megyei Levéltár. Kaposvár.

Thassy J. (1999): Hátraarc. Balassi Kiadó. Budapest.

Valuch T. (1999): Magyarország társadalomtörténete a XX. század második felében. Osiris Kiadó. Budapest. 